\title{
Behavioral Evidence for More than One Taste Signaling Pathway for Sugars in Rats
}

\author{
Lindsey A. Schier and Alan C. Spector \\ Department of Psychology and Program in Neuroscience, Florida State University, Tallahassee, Florida 32306
}

By conventional behavioral measures, rodents respond to natural sugars, such as glucose and fructose, as though they elicit an identical perceptual taste quality. Beyond that, the metabolic and sensory effects of these two sugars are quite different. Considering the capacity to immediately respond to the more metabolically expedient sugar, glucose, would seem advantageous for energy intake, the present experiment assessed whether experience consuming these two sugars would modify taste-guided ingestive responses to their yet unknown distinguishing orosensory properties. One group $(\mathrm{GvF})$ had randomized access to three concentrations of glucose and fructose $(0.316,0.56,1.1 \mathrm{M})$ in separate 30 -min single access training sessions, whereas control groups received equivalent exposure to the three glucose or fructose concentrations only, or remained sugar naive. Comparison of the microstructural licking patterns for the two sugars revealed that GvF responded more positively to glucose (increased total intake, increased burst size, decreased number of pauses), relative to fructose, across training. As training progressed, GvF rats began to respond more positively to glucose in the first minute of the session when intake is principally taste-driven. During post-training brief-access taste tests, GvF rats licked more for glucose than for fructose, whereas the other training groups did not respond differentially to the two sugars. Additional brief access testing showed that this did not generalize to Na-saccharin or galactose. Thus, in addition to eliciting a common taste signal, glucose and fructose produce distinct signals that are apparently rendered behaviorally relevant and hedonically distinct through experience. The taste pathway(s) underlying this remain to be identified.

Key words: appetition; gustatory system; licking microstructure; sweeteners; T1R2+T1R3; taste receptors

\section{Significance Statement}

The T1R2+T1R3 heterodimer is thought by many to be the only taste receptor for sugars. Although most sugars have been conventionally shown to correspondingly produce a unitary taste percept (sweet), there is reason to question this model. Here, we demonstrate that rats that repeatedly consumed two metabolically distinct sugars (glucose and fructose), and thus have had the opportunity to associate the tastes of these sugars with their differential postoral consequences, initially respond identically to the orosensory properties of the two sugars but eventually respond more positively to glucose. Thus, in addition to the previously identified common taste pathway, glucose and fructose must engage distinct orosensory pathways, the underlying molecular and neural mechanisms of which now await discovery.

\section{Introduction}

Despite varying in structure and metabolic pathway, many of the sugars and chemicals coincident with sugars in nature (e.g., sugar alcohols) elicit a shared perceptual taste quality ("sweet"), as inferred from a number of different behavioral and psychophysical

\footnotetext{
Received Sept. 8, 2015; revised 0ct. 18, 2015; accepted Nov. 12, 2015.

Author contributions: L.A.S. and A.C.S. designed research; L.A.S. performed research; L.A.S. analyzed data; L.A.S. and A.C.S. wrote the paper.

This work was supported by National Institute on Deafness and Other Communication Disorders Grants R01-DC009821 (to A.C.S.) and F32-DC-013494 (to L.A.S.) Emplex was generously supplied by Caravan Ingredients. The authors declare no competing financial interests.

Correspondence should be addressed to Dr. Alan C. Spector, Department of Psychology and Program in Neuroscience, Florida State University, 1107 West Call Street, Tallahassee, FL 32306. E-mail: Spector@psy.fsu.edu. DOI:10.1523/JNEUROSCI.3356-15.2016

Copyright $\odot 2016$ the authors $\quad 0270-6474 / 16 / 360113-12 \$ 15.00 / 0$
}

measures (e.g., Nissenbaum and Sclafani, 1987; Breslin et al., 1996; Dotson and Spector, 2007). Accordingly, the gustatory system is commonly thought to have evolved a broadly tuned "sweet" taste receptor that not only facilitates the detection of these various compounds in the environment but is inherently linked to behavioral and physiological reflexes that promote their consumption and prepare the body for their arrival. This model was significantly bolstered by the discovery of a receptor (the T1R2+T1R3 heterodimer), which binds with sugars, as well as with other known "sweet" chemicals (Nelson et al., 2001; Li et al., 2002) and subsequent demonstrations that genetic deletion of one or more of these proteins (T1R2, T1R3 or T1R2+T1R3) in knock-out mice severely disrupts, if not completely abolishes, electrophysiological responsivity, and behavioral sensitivity and attraction to these ligands (Damak et al., 2003; e.g., Zhao 
et al., 2003; Treesukosol et al., 2011; Treesukosol and Spector, 2012).

Although the importance of the T1R2 + T1R3 heterodimer in sweet taste transduction is indisputable, it remains possible that other receptors and/or signaling pathways may also contribute, at least for some ligands. For example, although unmotivated to lick for glucose, sucrose, and fructose, T1R3 knock-out mice evince normal cephalic phase insulin responses (CPIR) to the tastes of glucose and sucrose, but, like wild-types, not to fructose (Glendinning et al., 2015). Thus, it may be that the residual T1R2+T1R3-independent responses to sugars that have been commonly observed in T1R3 knock-out mice (e.g., Damak et al., 2003; Ohkuri et al., 2009; Glendinning et al., 2015) are linked to separate behavioral and/or physiological outputs than conventionally measured. Arguably, the capacity to respond generally (even predominately) to various sweet compounds via one receptor does not necessarily preclude the capacity to also respond differentially among them via separate receptors/signaling pathways in other circumstances or for separate functions (Spector and Glendinning, 2009). That is, while a single receptor strategy is expedient for some purposes, there could be adaptive value in the ability to distinguish among sugars for others (e.g., only preemptively release insulin in response to substances containing glucose).

With respect to sugars, there is a good deal of evidence that their postoral consequences differentially feedback to temper tasteguided responses, both within the meal and over the long-term. Postoral glucose appears to be particularly effective at reinforcing ingestion, as well as preferences for associated flavors. By comparison, calorie-matched postoral fructose exerts weak effects, at best (e.g., Sclafani and Ackroff, 1994, 2012b). It is tempting to further speculate that some of the differential efficacies among equicaloric nutrients to modulate intake and choice (e.g., glucose vs fructose) better reflect the metabolic hierarchies among them and, as such, provide a means for disambiguating novel, equally preferred, or similar tasting foods and fluids via learning.

Here, we tested the hypothesis that glucose and fructose elicit distinct orosensory signals that can be rendered behaviorally significant through learning. Taking experimental advantage of the fact that rodents learn to prefer orosensory signals associated with postoral glucose, but not fructose, rats were exposed to both sugars in separate 30 -min training sessions, permitting the opportunity to experience the varied sensory and metabolic corollaries of consuming each sugar. Separate control groups were exposed to just one sugar during these training sessions. We then tested all rats in brief access taste tests in which immediate lick responses to glucose and fructose solutions were compared with responses of a group that remained sugar-naive throughout training. As the results will attest, only the rats trained with both sugars demonstrated preferential licking of glucose over fructose on the basis of the orosensory properties of these stimuli in the brief access taste test posing a significant challenge to the single sugar receptor model.

\section{Materials and Methods}

\section{Subjects}

Twenty-eight naive adult male Sprague Dawley rats were singly housed in standard polycarbonate cages in a climate controlled room on a $12 \mathrm{~h}: 12 \mathrm{~h}$ light: dark cycle. All training and testing sessions were conducted during the light phase. Rats had ad libitum access to rodent chow (Labdiet 5001, Purina) and deionized water $\left(\mathrm{dH}_{2} \mathrm{O}\right)$ in the homecage, except as noted below in Behavioral procedures. All experimental protocols were approved by and conducted in accordance with the Florida State University Animal Care and Use Committee.
Table 1. Training groups, training and testing schedule, and stimuli

\begin{tabular}{|c|c|c|c|c|c|}
\hline & & \multicolumn{4}{|c|}{ GROUPS and STIMULI } \\
\hline Sess & $\begin{array}{l}\text { Dep. } \\
\text { state }\end{array}$ & $\begin{array}{l}\text { GvF } \\
(n=9)\end{array}$ & $\begin{array}{l}\text { Glu- } \\
\text { Only } \\
(n=6)\end{array}$ & $\begin{array}{l}\text { Fru- } \\
\text { Only } \\
(n=5)\end{array}$ & $\begin{array}{c}\text { Sugar- } \\
\text { naïve } \\
(n=8)\end{array}$ \\
\hline \multicolumn{6}{|c|}{ SPOUT TRAINING for SINGLE ACCESS SESSIONS } \\
\hline $1-3$ & water & \multicolumn{4}{|c|}{$\mathrm{dH}_{2} \mathrm{O}$} \\
\hline $4-6$ & food & \multicolumn{4}{|c|}{$4.5 \% \mathrm{COe}$} \\
\hline \multicolumn{6}{|c|}{ SINGLE ACCESS TRAINING SESSIONS } \\
\hline 7 & \multirow{7}{*}{ 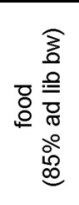 } & $0.56 \mathrm{G}^{*}$ & $0.56 \mathrm{G}$ & $0.56 \mathrm{~F}$ & $4.5 \mathrm{COe}$ \\
\hline 8 & & $1.1 \mathrm{~F}$ & $1.1 \mathrm{G}$ & $1.1 \mathrm{~F}$ & $8.9 \mathrm{COe}$ \\
\hline 9 & & $0.316 \mathrm{~F}$ & $0.316 \mathrm{G}$ & $0.316 \mathrm{~F}$ & $2.5 \mathrm{COe}$ \\
\hline 10 & & $1.1 \mathrm{G}$ & $1.1 \mathrm{G}$ & $1.1 \mathrm{~F}$ & $8.9 \mathrm{COe}$ \\
\hline 11 & & $0.56 \mathrm{~F}$ & $0.56 \mathrm{G}$ & $0.56 \mathrm{~F}$ & $4.5 \mathrm{COe}$ \\
\hline 12 & & $0.316 \mathrm{G}$ & $0.316 \mathrm{G}$ & $0.316 \mathrm{~F}$ & $2.5 \mathrm{COe}$ \\
\hline $13-24$ & & $\vdots$ & $\vdots$ & $\vdots$ & $\vdots$ \\
\hline \multicolumn{6}{|c|}{ BRIEF ACCESS TRAINING: STATIONARY SPOUT } \\
\hline $25-26$ & water & \multicolumn{4}{|c|}{$\mathrm{dH}_{2} \mathrm{O}$} \\
\hline \multicolumn{6}{|c|}{ BRIEF ACCESS TRAINING: 15 -s TRIALS } \\
\hline $27-28$ & water & \multicolumn{4}{|c|}{$\mathrm{dH}_{2} \mathrm{O}$} \\
\hline 29 & food & \multicolumn{4}{|c|}{$4.5 \% \mathrm{COe}$} \\
\hline \multicolumn{6}{|c|}{ BRIEF ACCESS TESTS: GLUCOSE VERSUS FRUCTOSE } \\
\hline 30 & Ad lib & \multirow{4}{*}{\multicolumn{4}{|c|}{$\begin{array}{l}\text { glucose: } 0.316,0.56,1.1 \mathrm{M} \\
\text { fructose: } 0.316,0.56,1.1 \mathrm{M}\end{array}$}} \\
\hline 31 & food & & & & \\
\hline 32 & Ad lib & & & & \\
\hline 33 & food & & & & \\
\hline \multicolumn{6}{|c|}{ BRIEF ACCESS TEST: Na-SACCHARIN } \\
\hline 34 & food & \multicolumn{4}{|c|}{$0\left(\mathrm{dH}_{2} \mathrm{O}\right), 0.03,0.1,0.5,1,5,10,50 \mathrm{mM}$} \\
\hline \multicolumn{6}{|c|}{ BRIEF ACCESS TEST: GALACTOSE } \\
\hline 35 & food & \multicolumn{4}{|c|}{$0\left(\mathrm{dH}_{2} \mathrm{O}\right), 0.03,0.06,0.12,0.24,0.48,0.96 \mathrm{M}$} \\
\hline \multicolumn{6}{|c|}{ BRIEF ACCESS TEST: Na-SACCHARIN vs GALACTOSE } \\
\hline 36 & food & \multicolumn{4}{|c|}{$\begin{array}{l}\text { Na-Saccharin: } 0.5,5,10 \mathrm{mM} \\
\text { galactose: } 0.24,0.48,0.96 \mathrm{M}\end{array}$} \\
\hline
\end{tabular}

Single access training stimuli were presented in randomized order without replacement across each trial block. This schedule resulted in three 6-d trial blocks for the GvF group and six 3-d trial blocks for the Glu-only, Fru-only, and sugar-naive training groups for a total of 18 sessions. GvF, Glucose versus fructose training group; Glu-only, glucose only training group; Fru-only, fructose only training group; $\mathrm{COe}$, corn oil emulsion; $\mathrm{dH}_{2} \mathrm{O}$, deionized water; sess., sessions; dep state, deprivation state; Ad lib, ad libitum.

*Approximately half of the rats in the GvF group received $0.56 \mathrm{~m}$ glucose on the very first session, while the other half received $0.56 \mathrm{~m}$ fructose. Sugars were presented in the indicated molar ( $\mathrm{M}$ ) concentrations. For brief access testing, stimuli were serially presented in 15 -s trials in a randomized order across blocks of trials (without replacement).

\section{Training and test stimuli}

All taste stimuli were prepared fresh each morning with $\mathrm{dH}_{2} \mathrm{O}$. Glucose (BDH Chemicals), fructose, Na-saccharin, and galactose (Sigma Aldrich) were all reagent grade. Corn oil emulsions were made by mixing (v/v) $2.5 \%, 4.5 \%$, or $8.9 \%$ corn oil (Winn Dixie Brand) with $0.6 \%$ of an emulsifying agent (Emplex, generously provided by Caravan Ingredients), and $\mathrm{dH}_{2} \mathrm{O}$ in a standard kitchen blender. These emulsions were initially mixed fresh each morning before the start of the training sessions and were then periodically remixed throughout the day to help ensure that all of the rats were receiving corn oil that was fully emulsified. All training and testing stimulus concentrations are listed in Table 1.

\section{Apparatus}

All training and testing sessions were conducted in one of four identical gustometers (for a full description, see Spector et al., 2015). Briefly, each gustometer comprises a modified operant chamber with three equally spaced access slots on the front panel (left, center, right) and an interfacing computer-controlled fluid stimulus delivery system and lick response measurement system. The schedule of access to the training and testing stimuli and the manner in which the stimuli were delivered differed for the single access training sessions and the brief access test sessions; for clarity's sake, these are described in detail in the respective subsections of Behavioral procedures below.

\section{Behavioral procedures}

Spout training for single access sessions. These sessions were referred to as single access sessions because a single stimulus was available during any given session, but the stimulus could vary in either concentration or compound across sessions. All sessions were conducted in the gustom- 
eter, which is specially designed to measure immediate licking responses at sample spout/ball (with millisecond resolution) and yoke that to the delivery of tightly controlled volumes of the stimulus through a single access spout.

All rats were initially water-deprived $(\sim 22 \mathrm{~h})$ and placed into the gustometer for $30 \mathrm{~min}$ on each of three consecutive days to acquaint them to licking for continuous access to a single fluid $\left(\mathrm{dH}_{2} \mathrm{O}\right)$ at a stainless steel spout (a $17 \mathrm{G}$ tube). This spout was mounted within a stationary Teflon polytetrafluorethylene ball that was positioned just behind the right access slot. Each lick at the ball was registered by a load cell and programmed to operate a stepping motor. This, in turn, drove an externally mounted syringe to dispense $\sim 5 \mu \mathrm{l}$ of $\mathrm{dH}_{2} \mathrm{O}$ via polyethylene tubing to the spout. In effect, this system allowed the rat to continuously obtain fluid during active licking at a fixed rate of $5 \mu \mathrm{l} /$ lick. Water bottles were returned on the homecages $\sim 30 \mathrm{~min}$ after the third and final $\mathrm{dH}_{2} \mathrm{O}$ session. Rats were given $1 \mathrm{~d}$ to replete in the homecage (no training session), before chow was removed for the second phase of spout training. This phase was simply designed to familiarize the now food-deprived rats with obtaining a caloric solution at the right spout. Thus, as the rats were gradually reduced to $85 \%$ of their ad libitum body weights by rationing their daily chow, they were given daily 30 -min access to a nonsugar caloric solution ( $4.5 \%$ corn oil emulsion), instead of the $\mathrm{dH}_{2} \mathrm{O}$, in three consecutive daily sessions. Four of the 28 rats failed to take at least 300 licks during any of these sessions, and so, after the third session, were provided a bottle containing $5 \mathrm{ml}$ of the $4.5 \%$ of the corn oil emulsion on the homecage overnight. The next day, these four rats were given an additional 30-min spout training session with the corn oil emulsion; all four met the lick criterion ( $\geq 300$ licks). The daily ration of chow was provided in the homecage $\sim 30 \mathrm{~min}$ after the conclusion of each daily session. By the end of this phase, all rats were at $85 \%$ of their ad libitum body weight and were maintained at this level throughout the remainder of the training phase. At the conclusion of spout training, rats were divided into four training groups that were matched for mean \pm SD corn oil emulsion intake on the final training session and body weight on that same day.

Single access training sessions. The training groups, sample sizes, and their respective training stimuli are listed in Table 1. Single access training sessions were conducted exactly as described for the spout training phase above, except that each group was only given access to their respective training stimuli, in place of $\mathrm{dH}_{2} \mathrm{O}$, at the right spout, over 18 consecutive daily 30 -min sessions. This phase was divided into 3 six-sessiontrial-blocks (for GvF) or 6 three-session-trial-blocks for the remaining groups. Each stimulus was presented once per trial block, with the order of stimulus presentation randomized across trial blocks. That is with exception of the very first training session during which all sugar-trained rats were given access to the middle concentration of their respective training stimulus. For the GvF group, this meant that approximately half the rats started with $0.56 \mathrm{~m}$ glucose, whereas the other half started with $0.56 \mathrm{~m}$ fructose. Beginning on the second session and for the remaining 18 sessions, the randomized schedule progressed as described above. The daily ration of chow was provided in the homecage $\sim 30 \mathrm{~min}$ after the end of each training session. Following the 18 day training phase, rats were once again returned to ad libitum chow and allowed $3 \mathrm{~d}$ to replete before the start of brief access training. All lick records were analyzed off-line for changes in microstructural lick patterns, both within the session and across sessions as a function of stimulus/concentration and trial.

Brief access apparatus and trial structure. In the brief access test, the rats were presented with an array of taste stimuli (i.e., 6 or 7 different solutions/concentrations) in a serial randomized order across blocks (without replacement) of 15-s trials in each 30-min session. This trial length was chosen to optimize the opportunity for differences in licking across stimuli and concentrations to be expressed while still minimizing the postoral contributions to the immediate licking response. The basic testing paradigm has been previously described in detail (Davis, 1973; Spector, 2003). All brief access training and testing took place in the gustometers. Each gustometer is equipped with a turret that holds up to 14 separate stimulus delivery tubes. Proximate to this turret and just behind the center access slot of the chamber is a borosilicate glass "sample" ball, which is mounted on a mechanical arm by a horizontal axle. At the start of each trial, the mechanical arm positions the sample ball between the turret and the center access slot. At the same time, the turret is oriented so that the program-specified tube is in line with the ball. Once the ball is in place at the center slot, a houselight illuminates and the rat has the opportunity to initiate a trial. The rat initiates a 15 -s trial by licking at least twice within a $250 \mathrm{~ms}$ period. Each lick in the ensuing $15 \mathrm{~s}$ activates the program-specified syringe pump to dispense $5 \mu \mathrm{l}$ of the stimulus onto the sample ball. Thus, with this arrangement, as the rat licks the sample ball, the ball rotates and brings the fluid that is dispensed onto the sample ball into the oral cavity. At the end of the 15-s trial, the sample ball is retracted, washed with $\mathrm{dH}_{2} \mathrm{O}$, and dried with pressurized air before the next trial $(\sim 6 \mathrm{~s})$. A vacuum tube is located just over the center slot that continuously draws air out of the area to preclude odor cues.

Brief access training. All rats were water-deprived $(\sim 22 \mathrm{~h})$ and acquainted with obtaining fluid at a different location of the chamber (center ball) across five 30-min sessions. In the first two of these, rats had continuous access (contingent upon active licking) to $\mathrm{dH}_{2} \mathrm{O}$ at the center sample ball (i.e., no trials). Then, for the next two sessions, rats were presented with $\mathrm{dH}_{2} \mathrm{O}$ in the 15 -s trial structure described above. Water bottles were replaced on the homecage $\sim 30 \mathrm{~min}$ after the end of the second of these two sessions. Following a $1 \mathrm{~d}$ repletion break, chow was removed from the homecage $\sim 22 \mathrm{~h}$ before the fifth and final training session. In this session, rats were presented with a $4.5 \%$ corn oil emulsion in discrete 15-s trials (as described above). Chow was returned on the homecage $\sim 30 \mathrm{~min}$ after the end of this final training session and brief access testing began the following day.

Brief access testing. The schedule of tests, test stimuli, and corresponding deprivation conditions are outlined in Table 1. All training groups were subjected to identical test schedules, stimuli, and conditions. All tests lasted $30 \mathrm{~min}$, during which time the rat was free to initiate as many trials as possible. In all cases, for testing, food deprivation was acute, with chow removed $\sim 22 \mathrm{~h}$ before test and returned $\sim 30 \mathrm{~min}$ after the conclusion of the test session. Rats were given a single 30-min test session per day. The four glucose versus fructose tests were run on consecutive days. Ten days after the conclusion of that, rats were tested with $\mathrm{Na}$-saccharin, galactose, and $\mathrm{Na}$-saccharin versus galactose in separate brief access test sessions, each separated by at least $2 \mathrm{~d}$.

\section{Data analyses}

For all analyses, $p$ values $\leq 0.05$ were considered statistically significant. To aid with clarity of presentation, the full statistical outcomes from some of the two- and three-way ANOVAs are presented in tables that are referenced in the text. In some places, statistical outcomes are referenced in the corresponding figure legend (as indicated).

Single access training sessions. The time-stamped lick records for each single access training session were used to calculate total licks, licks per minute, pauses (in active licking) per minute, average lick burst size per $30 \mathrm{~min}$ session, average number of pauses per $30 \mathrm{~min}$ session, and initial lick rate (i.e., total licks per the first minute of the session, calculated from the start time of the second lick). Based on previous research, a pause criterion of $\geq 1$ $s$ was set to determine the end of a licking burst and the start of another (Spector et al., 1998). Burst size was determined by tallying the total number of licks within a given burst (i.e., between two pauses). Repeated-measures ANOVAs were conducted to compare the Glu-only and Fru-only groups (between subjects) on each of these measures as a function of stimulus concentration and training trial. Separate repeated-measures ANOVAs were conducted on the GvF group to compare their responses with each sugar in a within-subjects fashion. A computer error caused the lick records for one training session of a single GvF rat to be lost; thus, this rat's data were excluded from all of the single access session analyses. But because this error did not interfere with the session itself and, therefore, did not disrupt training in any way, this rat was continued in the experiment as normal and was included for brief access testing.

Brief access tests. To compare relative lick responses across the various stimuli in a given test, the individual rat's average licks to each stimulus were standardized to its own estimated maximal lick rate [average licks to the stimulus/maximal lick rate $=$ standardized lick ratio]. Maximal lick rate was derived by first taking the average interlick interval on the sec- 
ond day of stationary brief access training on $\mathrm{dH}_{2} \mathrm{O}$, converting that to average licks per second, and then multiplying that value by $15 \mathrm{~s}$ (trial duration). Standardized lick ratios on each brief access test were compared as a function of training group and stimulus type and/or stimulus concentration with separate repeated-measures ANOVAs. The initial glucose versus fructose brief access test included four total test sessions (Table 1): two ad libitum and two food deprived. Separate repeatedmeasures ANOVAs were conducted for each test condition (collapsing across the two separate test sessions). Additionally, the number of trials initiated on each test condition were analyzed in separate ANOVAs. One rat in the Fru-only group failed to take enough trials to complete at least one full trial block on one of the ad libitum glucose versus fructose tests; therefore, this rat's data were excluded from the analyses on the standardized lick ratios but included in the analyses of the number of trials initiated, for the ad libitum tests.

\section{Results}

\section{Single access training}

Sugar-trained groups

The purpose of this phase of the study was to give a group of rats ( GvF) explicit opportunity to consume both glucose and fructose in separate short (30-min) daily sessions to determine whether these rats would learn to associate any putative differences in the orosensory properties of these two sugars with their distinct postoral consequences. To preclude rats from simply attending to a perceived "intensity" difference among the sugars, all GvF rats were presented with three isomolar/isocaloric concentrations of each sugar with overlapping intensity ranges in a randomized order across successive trial blocks. Finally, to determine whether simple exposure to one sugar, but not the other, was sufficient to foster such discriminative responding to the orosensory properties of the two sugars later on, separate groups of rats were given either just the three concentrations of glucose (Glu-only) or just the three concentrations of fructose (Fru-only) during this training phase.

On the first session of training, approximately half of all of the sugar-trained rats were given $0.56 \mathrm{M}$ glucose (including some of those destined for the GvF group and all of those destined for the Glu-only group) and the remaining rats were given $0.56 \mathrm{M}$ fructose (including some of those destined for the GvF group and all of those destined for the Fru-only group). This enabled comparison of the unconditioned licking responses to each of these sugars on the very first exposure. As shown in Figure $1 A$, rats consuming glucose licked at a faster rate and ingested more sugar overall than did rats consuming fructose $\left(F_{(1,17)}=23.28, p=\right.$ $0.0002)$. This difference was not immediate, though. At the beginning of a meal ingested stimuli principally engage the receptors of the oral cavity, and only with continued ingestion, begin to additionally act on postoral receptors. Thus, early measures, such as the lick rate in the first minute, reflect responses driven by the orosensory properties of the stimulus, at a point in time when the influence of postoral signals are minimized (e.g., Spector and St. John, 1998; Spector et al., 1998). As shown in Figure 1C, rats initially responded similarly to the orosensory properties of these
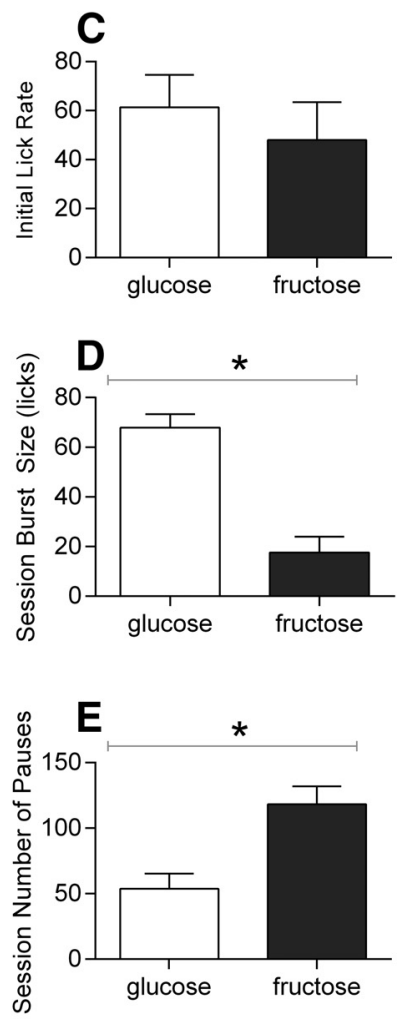

glucose

fructose

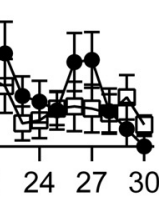

$* \wedge+$

Time (min)

$24 \quad 27 \quad 30$

.

Figure 1. Mean \pm SEM licks per minute for $0.56 \mathrm{~m}$ glucose $(n=12)$ or $0.56 \mathrm{~m}$ fructose $(n=8)$ across the first 30 -min training $(\boldsymbol{A})$ and corresponding mean \pm SEM pauses in active licking per minute $(\boldsymbol{B})$. Mean \pm SEM lick rates in the first minute of the session $(\boldsymbol{C})$, overall burst size $(\boldsymbol{D})$, and number of pauses $(\boldsymbol{E})$ for the first 30-min session. * Significant main effect of stimulus. $\wedge$ Significant main effect of time. ${ }^{+}$Significant stimulus $\times$time interaction.

two sugars $\left(F_{(1,17)}=0.44, p=0.52\right)$. Shortly thereafter, however, a clear difference emerged (Fig. $1 A$ ). Rate of licking rapidly increased for glucose and remained elevated for several minutes, before gradually slowing again toward the end of the session. Rate of licking for fructose, on the other hand, remained relatively low and stable, with the exception of a transient increase approximately halfway into the session, before likewise slowing toward the end of the session $\left(F_{(29,493)}=3.87, p<0.00001\right)$.

Microstructurally, the licking behavior of a rat is highly stereotyped, comprising a series of rapid licks (i.e., bursts), separated by longer pauses (e.g., Davis and Smith, 1992; Spector et al., 1998). Both the size of these active licking bursts and the number of pauses between them vary systematically with the positive and negative feedback signals generated by the stimulus as it engages sensors and other processes along the alimentary tract (Davis and Smith, 1992). Generally speaking, burst size increases and the number of pauses decreases as a function of stimulus palatability (Davis and Perez, 1993; Spector et al., 1998; Spector and St. John, 1998). To date, the effects of postoral feedback signals on licking microstructure have been primarily examined in terms of negative feedback (i.e., satiation processes), which are principally thought to inhibit the initiation of a licking burst after a pause, but also appear to inhibit active licking (i.e., reducing burst size) (for review, see Davis, 1999). Figure $1 B$ shows the number of pauses in each successive 1-min bin of the session. Comparison of this response measure with the corresponding number of licks in Figure $1 A$ reveals that the stimulation generated by glucose ingestion initially functions to increase licking burst size, with the licks increasing and the number of pauses remaining relatively stable, and then, toward the end of the 

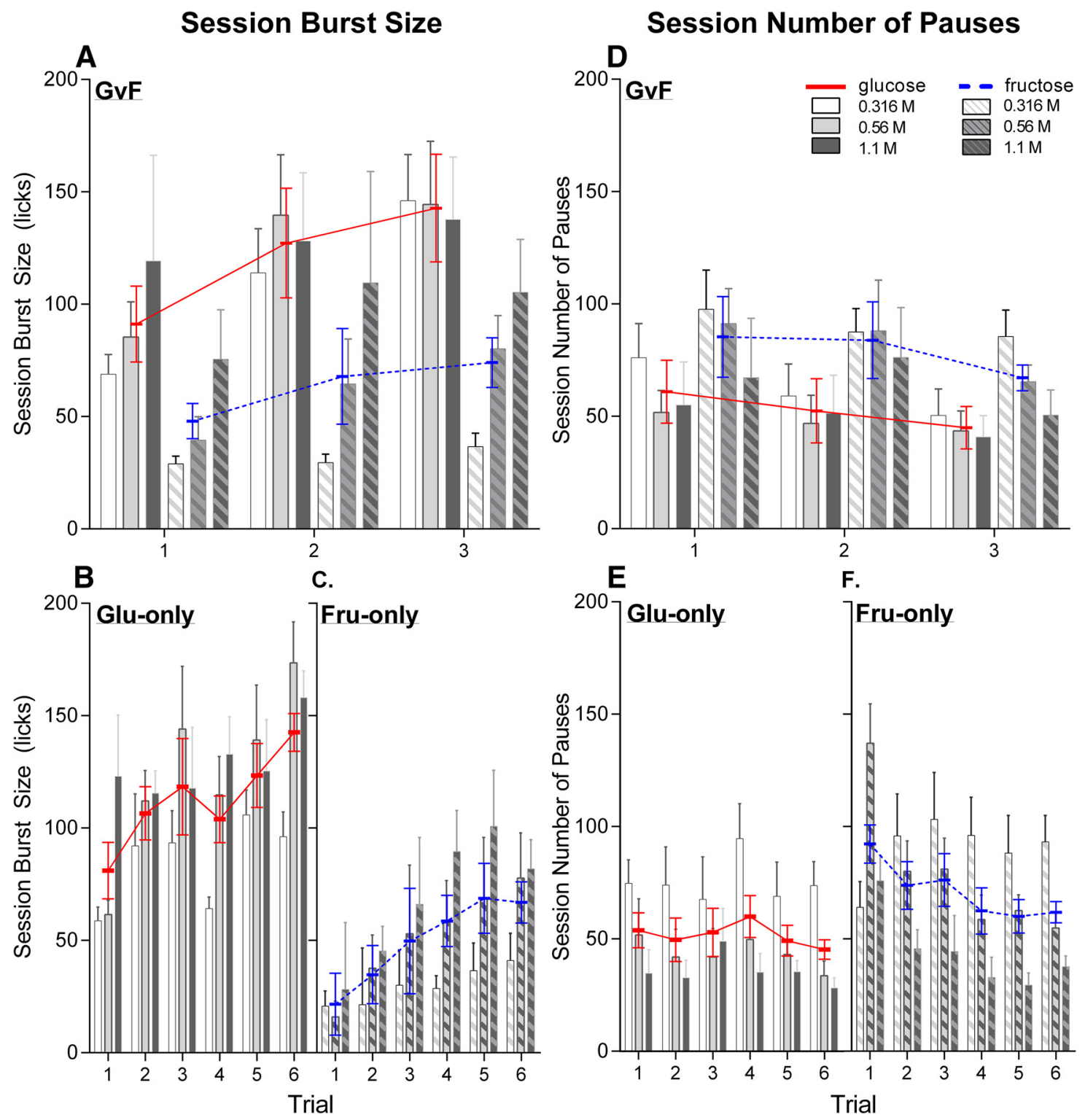

Figure 2. Mean \pm SEM burst size and number of pauses taken by the GvF group ( $A$ and $\boldsymbol{D}$, respectively) on glucose versus fructose sessions, as a function of concentration, across single access training trials. Mean \pm SEM burst size and number of pauses taken by the Glu-only group ( $\boldsymbol{B}$ and $\boldsymbol{E}$, respectively) and Fru-only group ( $\boldsymbol{C}$ and $\boldsymbol{F}$, respectively) on their respective training sugars, as a function of concentration, across single access training trials. Solid red lines indicate the overall mean \pm SEM burst sizes or number of pauses on glucose sessions (collapsed across concentration) at each trial. Dashed blue lines indicate the overall mean \pm SEM burst sizes or number of pauses on fructose sessions (collapsed across concentration) at each trial. The corresponding ANOVA results are presented in Tables 2 and 3.

session, both burst size and number of pauses (and therefore bursts) decrease. Fructose, on the other hand, was ingested in many small bursts of licks, at least in the first half of the session and again toward the end of the session $\left(F_{(29,493)}=1.50, p=\right.$ 0.05). Around the midpoint of the session, there did appear to be a transient shift toward increased licking, with correspondingly fewer pauses, though. Thus, while the orosensory properties of these isocaloric glucose and fructose solutions initially elicit a very similar response profile (i.e., within the first minute), these sugars appear to rapidly elicit distinct responses thereafter; the precise sites or receptive fields that contribute the differential signals under these testing conditions have yet to be determined. Mean ( \pm SEM) burst sizes and number of pauses for the entire 30-min session are shown in Figure $1 D$ and Figure $1 E$, respectively $\left(F_{(1,17)}=36.81, p=\right.$ 0.00001 and $F_{(1,17)}=13.03, p=0.002$, respectively).
These same general patterns of licking (i.e., average burst size and number of pauses) for each sugar remained consistent across the remainder of the training sessions. That is, the Glu-only group continued to consume their glucose solutions in large sustained bursts of licking, whereas the Fru-only group continued to exhibit the inverse pattern, marked instead by many smaller bursts of licking (Fig. 2 B, C,E, F; statistical outcomes in Table 2). Notably, burst size increased across training for both groups. Although the corresponding number of pauses also tended to decrease across trials in the Fru-only group, no marked change in corresponding pause number was evident for the Glu-only group. Burst size and pause number exhibited more or less a similar pattern of concentration dependency for both groups, but the fact that burst sizes across all concentrations of glucose were increased relative to all concentrations of fructose suggests that the glucose generated more positive feedback. Interestingly 
Table 2. ANOVA values on microstructural measures of licking in the Glu and Fru training groups for single access training

\begin{tabular}{|c|c|c|c|c|c|c|c|}
\hline $\begin{array}{c}\text { Lick } \\
\text { Parameter }\end{array}$ & $\begin{array}{l}\text { Group } \\
\text { Effect }\end{array}$ & $\begin{array}{l}\text { Conc. } \\
\text { Effect }\end{array}$ & Trial Effect & $\begin{array}{l}\text { Trial x } \\
\text { Conc. }\end{array}$ & $\begin{array}{l}\text { Trial x } \\
\text { Group }\end{array}$ & $\begin{array}{l}\text { Group x } \\
\text { Conc. }\end{array}$ & $\begin{array}{l}\text { Trial x } \\
\text { Group x } \\
\text { Conc. }\end{array}$ \\
\hline $\begin{array}{l}\text { Total } \\
\text { Licks }\end{array}$ & $\begin{array}{c}F(1,9)=14.67 \\
p=0.004\end{array}$ & $\begin{array}{c}F(2,18)=42.16 \\
p<0.00001\end{array}$ & $\begin{array}{c}F(5,45)=23.50 \\
p<0.00001\end{array}$ & $\begin{array}{c}F(10,90)=3.33 \\
p=0.001\end{array}$ & $\begin{array}{c}F(5,45)=0.45, \\
p=0.81\end{array}$ & $\begin{array}{c}F(2,18)=32.17 \\
p<0.00001\end{array}$ & $\begin{array}{c}F(10,90)=0.41 \\
p=0.94\end{array}$ \\
\hline $\begin{array}{c}\text { No. of } \\
\text { Pauses }\end{array}$ & $\begin{array}{c}F(1,9)=4.52 \\
p=0.06\end{array}$ & $\begin{array}{c}F(2,18)=19.27 \\
p<0.0001\end{array}$ & $\begin{array}{c}F(5,45)=2.33 \\
p=0.06\end{array}$ & $\begin{array}{c}F(10,90)=3.41 \\
p=0.0008\end{array}$ & $\begin{array}{c}F(5,45)=1.77 \\
p=0.14\end{array}$ & $\begin{array}{c}F(2,18)=2.11 \\
p=0.15\end{array}$ & $\begin{array}{c}F(10,90)=2.38 \\
p=0.01\end{array}$ \\
\hline $\begin{array}{c}\text { Burst } \\
\text { Size }\end{array}$ & $\begin{array}{c}F(1,9)=12.49 \\
p=0.006\end{array}$ & $\begin{array}{c}F(2,18)=22.24 \\
p=0.00001\end{array}$ & $\begin{array}{c}F(5,45)=11.57 \\
p<0.00001\end{array}$ & $\begin{array}{c}F(10,90)=1.43 \\
p=0.18\end{array}$ & $\begin{array}{c}F(5,45)=1.08 \\
p=0.38\end{array}$ & $\begin{array}{c}F(2,18)=0.93 \\
p=0.41\end{array}$ & $\begin{array}{c}F(10,90)=0.99 \\
p=0.46\end{array}$ \\
\hline $\begin{array}{c}\text { Initial } \\
\text { Lick Rate }\end{array}$ & $\begin{array}{c}F(1,9)=8.61 \\
p=0.02\end{array}$ & $\begin{array}{c}F(2,18)=4.48 \\
p=0.03\end{array}$ & $\begin{array}{c}F(5,45)=16.03 \\
p<0.00001\end{array}$ & $\begin{array}{c}F(10,90)=1.44 \\
p=0.18\end{array}$ & $\begin{array}{c}F(5,45)=0.67 \\
p=0.65\end{array}$ & $\begin{array}{c}F(2,18)=1.23 \\
p=0.32\end{array}$ & $\begin{array}{c}F(10,90)=1.93, \\
p=0.051\end{array}$ \\
\hline $\begin{array}{c}\text { Initial Lick } \\
\text { Rate Tr1 }\end{array}$ & $\begin{array}{c}F(1,9)=6.23 \\
p=0.03\end{array}$ & $\begin{array}{c}F(2,18)=3.01 \\
p=0.07\end{array}$ & & & & $\begin{array}{c}F(2,18)=2.80 \\
p=0.09\end{array}$ & \\
\hline $\begin{array}{l}\text { Initial Lick } \\
\text { Rate Tr2 }\end{array}$ & $\begin{array}{c}F(1,9)=4.87 \\
p=0.06\end{array}$ & $\begin{array}{c}F(2,18)=2.16 \\
p=0.14\end{array}$ & & & & $\begin{array}{c}F(2,18)=0.12 \\
p=0.89\end{array}$ & \\
\hline $\begin{array}{l}\text { Initial Lick } \\
\text { Rate Tr3 }\end{array}$ & $\begin{array}{c}F(1,9)=5.97 \\
p=0.03\end{array}$ & $\begin{array}{c}F(2,18)=8.33 \\
p=0.003\end{array}$ & & & & $\begin{array}{c}F(2,18)=7.18 \\
p=0.005\end{array}$ & \\
\hline $\begin{array}{l}\text { Initial Lick } \\
\text { Rate Tr4 }\end{array}$ & $\begin{array}{c}F(1,9)=3.14 \\
p=0.11\end{array}$ & $\begin{array}{c}F(2,18)=0.05 \\
p=0.995\end{array}$ & & & & $\begin{array}{c}F(2,18)=3.31 \\
p=0.06\end{array}$ & \\
\hline $\begin{array}{l}\text { Initial Lick } \\
\text { Rate Tr5 }\end{array}$ & $\begin{array}{c}F(1,9)=5.03 \\
p=0.052\end{array}$ & $\begin{array}{c}F(2,18)=0.58 \\
p=0.57\end{array}$ & & & & $\begin{array}{c}F(2,18)=0.09 \\
p=0.92\end{array}$ & \\
\hline $\begin{array}{c}\text { Initial Lick } \\
\text { RateTr6 }\end{array}$ & $\begin{array}{c}F(1,9)=2.58 \\
p=0.14\end{array}$ & $\begin{array}{c}F(2,18)=0.11 \\
p=0.89\end{array}$ & & & & $\begin{array}{c}F(2,18)=0.20 \\
p=0.82\end{array}$ & \\
\hline
\end{tabular}

Significant effects in italics. Tr., Trial; No., number.

Table 3. ANOVA values on microstructural measures of licking for the GvF training group on single access training

\begin{tabular}{|c|c|c|c|c|c|c|c|}
\hline $\begin{array}{c}\text { Lick } \\
\text { Parameter }\end{array}$ & $\begin{array}{l}\text { Stimulus } \\
\text { Effect }\end{array}$ & Conc. Effect & Trial Effect & $\begin{array}{l}\text { Trial x } \\
\text { Conc. }\end{array}$ & $\begin{array}{c}\text { Trial } x \\
\text { Stimulus }\end{array}$ & $\begin{array}{l}\text { Stimulus x } \\
\text { Conc. }\end{array}$ & $\begin{array}{c}\text { Trial } \mathrm{x} \\
\text { Stimulus } \mathrm{x} \\
\text { Conc. }\end{array}$ \\
\hline Total Licks & $\begin{array}{c}F(1,7)=40.17, \\
p=0.0004\end{array}$ & $\begin{array}{c}F(2,14))=2.41 \\
p=0.13\end{array}$ & $\begin{array}{c}F(2,14)=21.39 \\
p=0.00001\end{array}$ & $\begin{array}{c}F(4,28)=0.62, \\
p=0.65\end{array}$ & $\begin{array}{c}F(2,14)=2.79 \\
p=0.10\end{array}$ & $\begin{array}{c}F(2,14)=19.56 \\
p=0.00009\end{array}$ & $\begin{array}{c}F(4,28)=1.48, \\
p=0.24\end{array}$ \\
\hline $\begin{array}{c}\text { No. of } \\
\text { Pauses }\end{array}$ & $\begin{array}{c}F(1,7)=21.03 \\
p=0.003\end{array}$ & $\begin{array}{c}F(2,14)=5.98 \\
p=0.01\end{array}$ & $\begin{array}{c}F(2,14)=1.95 \\
p=0.18\end{array}$ & $\begin{array}{c}F(4,28)=0.40 \\
p=0.81\end{array}$ & $\begin{array}{c}F(2,14)=0.30 \\
p=0.75\end{array}$ & $\begin{array}{c}F(2,14)=1.74 \\
p=0.21\end{array}$ & $\begin{array}{c}F(4,28)=0.79 . \\
p=0.54\end{array}$ \\
\hline Burst Size & $\begin{array}{c}F(1,7)=23.87, \\
p=0.002\end{array}$ & $\begin{array}{c}F(2,14)=5.52, \\
p=0.02\end{array}$ & $\begin{array}{c}F(2,14)=2.92 \\
p=0.09\end{array}$ & $\begin{array}{c}F(4,28)=0.21 \\
p=0.93\end{array}$ & $\begin{array}{c}F(2,14)=0.72 \\
p=0.50\end{array}$ & $\begin{array}{c}F(2,14)=4.71 \\
p=0.03\end{array}$ & $\begin{array}{c}F(4,28)=1.07, \\
p=0.39\end{array}$ \\
\hline $\begin{array}{c}\text { Initial Lick } \\
\text { Rate }\end{array}$ & $\begin{array}{c}F(1,7)=15.21, \\
p=0.006\end{array}$ & $\begin{array}{c}F(2,14)=27.70 \\
p=0.00001\end{array}$ & $\begin{array}{c}F(2,14)=37.72 \\
p<0.000001\end{array}$ & $\begin{array}{c}F(4,28)=6.76 \\
p=0.0006\end{array}$ & $\begin{array}{c}F(2,14)=0.44 \\
p=0.66\end{array}$ & $\begin{array}{c}F(2,14)=6.28 \\
p=0.01\end{array}$ & $\begin{array}{c}F(4,28)=0.49, \\
p=0.74\end{array}$ \\
\hline $\begin{array}{l}\text { Initial Lick } \\
\text { Rate Tr1 }\end{array}$ & $\begin{array}{c}F(1,7)=0.31 \\
p=0.59\end{array}$ & $\begin{array}{c}F(2,14)=80.13, \\
p<0.000001\end{array}$ & & & & $\begin{array}{c}F(2,14)=0.88 \\
p=0.44\end{array}$ & \\
\hline $\begin{array}{l}\text { Initial Lick } \\
\text { Rate Tr2 }\end{array}$ & $\begin{array}{c}F(1,7)=14.04, \\
p=0.007\end{array}$ & $\begin{array}{c}F(2,14)=7.88 \\
p=0.005\end{array}$ & & & & $\begin{array}{c}F(2,14)=8.06 \\
p=0.005\end{array}$ & \\
\hline $\begin{array}{l}\text { Initial Lick } \\
\text { Rate Tr3 }\end{array}$ & $\begin{array}{c}F(1,7)=7.29 \\
p=0.03\end{array}$ & $\begin{array}{c}F(2,14)=14.89 \\
p=0.0003\end{array}$ & & & & $\begin{array}{c}F(2,14)=2.59 \\
p=0.11\end{array}$ & \\
\hline
\end{tabular}

Significant effects in italics. Tr., Trial; No., number.

enough, the same discrepancy was evident in the group of rats that received both sugars. The GvF group continued to consume glucose in large bursts, with relatively few pauses, and consumed fructose in many small bursts. Burst size tended to increase and number of pauses tended decrease across trials for both sugars for the GvF group (Fig. 2A,D; statistical outcomes in Table 3).

Together, these respective patterns of licking yielded greater overall consumption of glucose in the 30 -min sessions, just as it had in the very first session. This was true for the betweensubjects and within-subjects comparisons (Fig. 3; Tables 2, 3). For the GvF group, consumption of glucose increased across trials, but the relationship between concentration and total intake remained consistent across this entire phase. Consumption of fructose remained relatively low, but also increased across trials, and did not vary in a systematic way with concentration (Fig. $3 A$ ).
Similarly, the Glu-only group increased consumption of all three glucose concentrations across trials while maintaining the same concentration dependency across the entire phase. The Fru-only group also increased fructose intake across training, but sugar intake in this group never reached the levels observed in the Gluonly group (Fig. $3 B, C$ ). Moreover, the Fru-only group showed a different pattern of concentration dependency, with consumption greatest at the middle concentration.

From the above measures, it is clear that the signals generated by each of these sugars are quite different, but the particular effects of taste cannot be parsed from those of postoral input. Thus, to track whether repeated exposure to such differential effects in turn modified responses to the orosensory signals generated by these two sugars, changes in the lick rate in the first minute of each session were compared. The GvF group started 


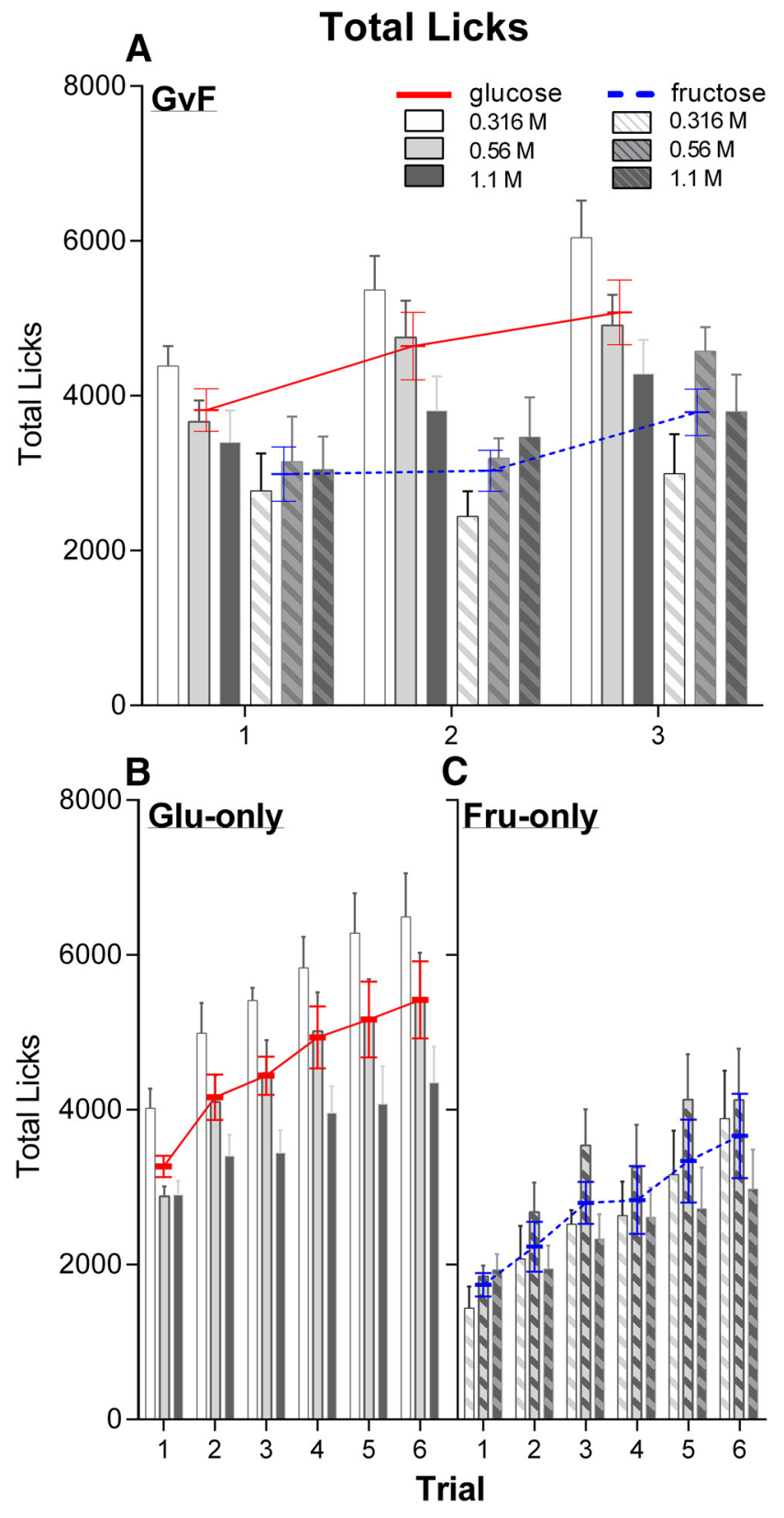

Figure 3. Mean \pm SEM total licks per session for GvF group and single sugar training groups on glucose ( $\boldsymbol{A}$ and $\boldsymbol{B}$, respectively) versus fructose ( $\boldsymbol{A}$ and $\boldsymbol{C}$, respectively) at each concentration across training trials. Solid red lines indicate the overall mean \pm SEM total licks to glucose (collapsed across concentration) across trials. Dashed blue lines indicate the overall mean \pm SEM total licks to fructose (collapsed across concentration) across trials. The corresponding three-way ANOVA results are presented in Tables 2 and 3.

out responding very similarly to glucose and fructose solutions in the first minute of each Trial 1 session (Fig. 4A; Table 3). As training progressed, the initial lick rate for glucose increased relative to that for fructose. This group licked with comparable vigor for the high concentration of each of these sugars in that first minute. The principal difference was in increased initial lick rates for the low and middle glucose concentrations, which rose to the level of the high concentrations by Trial 2. Initial lick rates for fructose remained more concentration-dependent throughout training. Together, these results suggest that GvF rats learned to respond to some orosensory signal from glucose that made it immediately discernible from fructose. By comparison, single- sugar training functioned to increase immediate responding to the low and middle concentrations of each sugar, although this was somewhat delayed in the Fru-only group (Fig. 4B, C; Table 2).

\section{Sugar-naive group}

A fourth training group remained sugar-naive during the training phase, and instead received three concentrations of a corn oil emulsion, matched in calories to the three sugar concentrations. As expected, intake of all three concentrations significantly increased across trial blocks (Fig. 5).

\section{Brief access tests}

Glucose versus fructose

Although the initial lick rate data from the training phase strongly suggested that the GvF group was responding to some distinguishing orosensory properties of the two sugars, it remained to be determined whether this would transfer to a situation in which the two sugars were presented within the same session and apart from their respective postoral effects. Therefore, all rats were first subjected to four brief access taste tests: two in a $22 \mathrm{~h}$ food deprived state and two in an ad libitum state, in which the three training concentrations of both sugars were serially presented in 15 -s trials in randomized order. Although the tests under food deprivation and ad libitum conditions were analyzed separately, because the response profiles were so similar, the results are described together here. Overall, all groups licked in a concentration-dependent manner, more or less emitting the greatest number of licks to the highest concentrations of glucose and fructose and the fewest number of licks to the lowest concentrations of glucose and fructose (Fig. 6; statistical outcomes in Table 4). The sugar-naive group responded identically to glucose and fructose across the tested concentrations. Despite having had extensive experience with one or the other sugar, so too did the Glu and Fru-only groups. The GvF group, on the other hand, licked significantly more for glucose than for fructose, especially at the low and middle concentrations. Thus, while the sugar-naive and single-sugar trained groups treated the two sugars identically at each concentration, the $\mathrm{GvF}$ group responded differently to the orosensory properties of glucose versus those of fructose. All four groups initiated comparable numbers of trials on these tests (means \pm SEMs and corresponding trial statistics presented in Fig. 6 legend).

\section{Na-saccharin}

To then assess whether sugar discrimination training affected how the GvF group responded to a different ligand for the T1R2+T1R3 heterodimeric receptor, all four groups were presented with six concentrations of Na-saccharin (and $\mathrm{dH}_{2} \mathrm{O}$ ) in a single 30-min brief access test session. The four training groups licked in a concentration-dependent manner for $\mathrm{Na}$-saccharin. Statistically speaking, a significant group $\times$ concentration interaction suggested differences among groups, but subsequent comparisons did not reveal any real systematic differences among groups, except that the GvF group licked more for the $0.5 \mathrm{~mm}$ concentration than the Fruonly and sugar-naive groups (Fig. 7A; for statistical outcomes, see Table 4). All training groups initiated a similar number of trials on this test (means \pm SEM and statistics presented in Fig. 7 legend).

\section{Galactose}

While the GvF group did not respond to the artificial sweetener in such a way that would suggest the prior experience impacted 


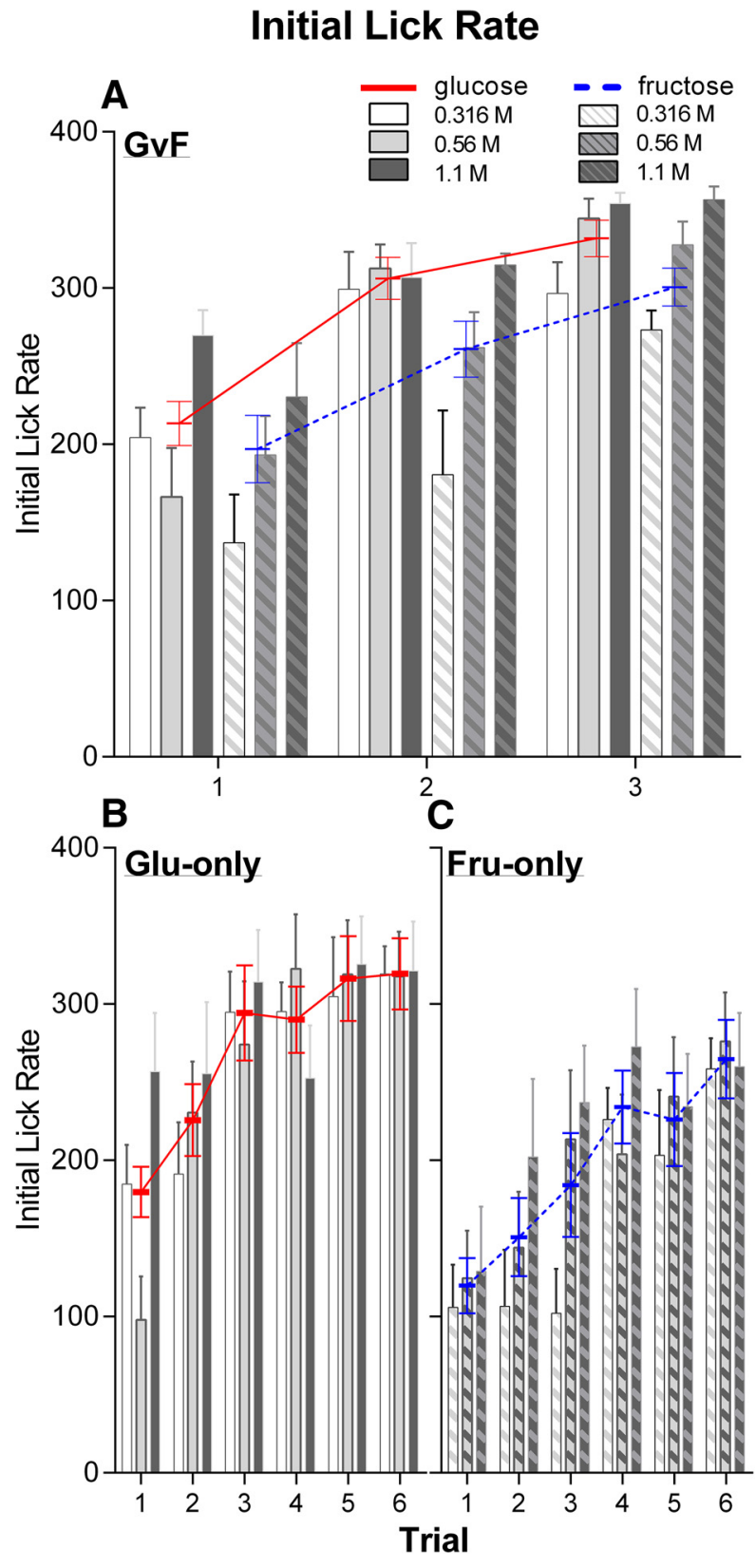

Figure 4. Mean \pm SEM licks in the first minute for glucose ( $\boldsymbol{A}$ and $\boldsymbol{B}$, respectively) or fructose ( $A$ and $C$, respectively) concentrations, for each sugar training group, across trials. Solid red lines indicate the overall mean \pm SEM initial lick rate on glucose sessions (collapsed across concentration) across trials. Dashed blue lines indicate the overall mean \pm SEM initial licks rate on fructose sessions (collapsed across concentration) across trials. The corresponding three-way ANOVA results are presented in Tables 2 and 3.

responsivity to a representative ligand known to bind with the T1R2+T1R3 heterodimer, it remained possible that the differences in responding to glucose that emerged with training may generalize to a novel third monosaccharide, galactose. A number of sugar transporters were recently identified in taste tissue, leading some to speculate they may function as auxiliary sugar sensors (Merigo et al., 2011; Toyono et al., 2011; Yee et al., 2011), like they seem to in other tissues (e.g., GI tract and CNS) (Dyer et al., 2003; O'Malley et al., 2006). Because most glucose transporters also mediate galactose, but not fructose, transport (Wright et al., 2012), the same sort of brief access test was conducted with six galactose concentrations (and $\mathrm{dH}_{2} \mathrm{O}$ ) in place of $\mathrm{Na}$-saccharin.

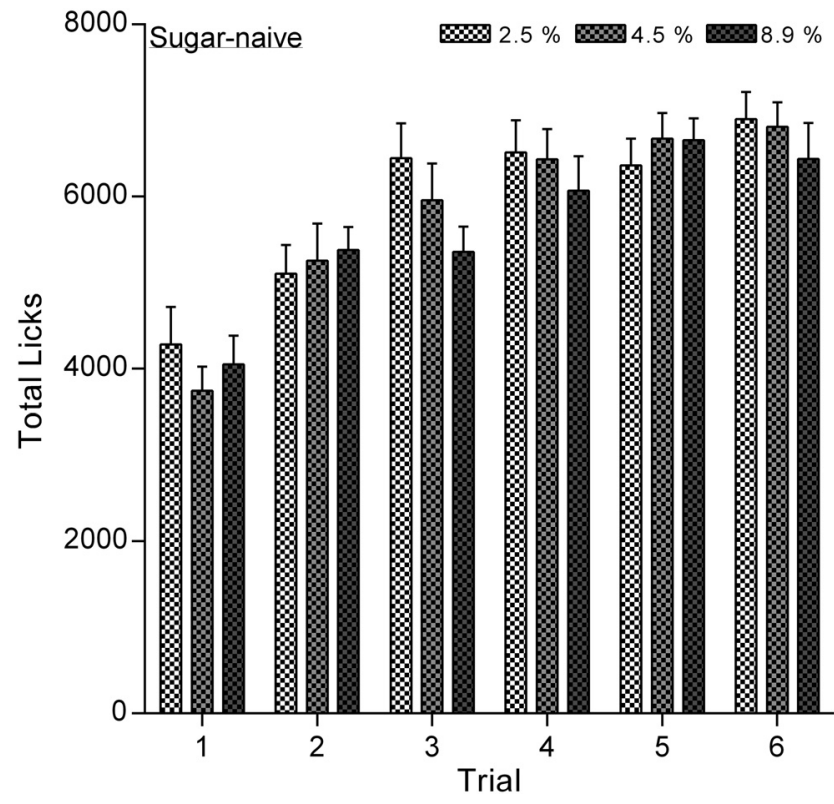

Figure 5. Mean \pm SEM total licks per session for sugar-naive group at each at each concentration of the corn oil emulsion across training trials. Main effect of trial: $F_{(5,35)}=40.45, p<$ 0.000001 ; main effect of concentration: $F_{(2,14)}=3.87, p=0.05$; trial $\times$ concentration: $F_{(10,70)}$ $=1.66, p=0.11$.

All four training groups licked to galactose in a concentrationdependent manner (Fig. 7B; for statistical outcomes, see Table 4). No significant main effects or interactions involving group on lick responses and the number of trials initiated confirm that training experience did not impact responding to this sugar.

$\mathrm{Na}$-saccharin versus galactose

While training history did not impact absolute responding to these two representative T1R1+T1R3 ligands (Na-saccharin and galactose), it remained possible that a difference would emerge if the rats were forced to directly compare the two within the same test session. Thus, three concentrations of $\mathrm{Na}$-saccharin and three concentrations of galactose, selected on the basis of the prior two tests, were randomly presented within a single test session. Yet, once again, there were no differences among the training groups (Fig. $7 C$; statistical outcomes in Table 4). Nor did training group affect the number of trials initiated in this test (with statistics presented in the Fig. 7 legend). These negative results, of course, do not preclude the involvement of these transporters in taste sensation; it may very well be that these transporters have altered affinities in taste tissue or perhaps are linked to different functions than those tested here.

\section{Discussion}

There is no question that the postoral sensory and metabolic corollaries of glucose and fructose are disparate. Numerous studies have already demonstrated that these differences manifest in the controls of ingestive behavior as well, including the facility to reinforce preferences for associated novel flavors (e.g., Sclafani and Ackroff, 1994, 2012b; Zukerman et al., 2013). Rather, the new finding here is that, following exposure to these respective repertoires, the orosensory properties of glucose were more effective at generating licking than those of fructose in the GvFtrained rats. This is, of course, fundamentally at odds with the prevailing view that simple sugars elicit identical orosensory sensations and, in turn, are inextricably linked to the same behav- 

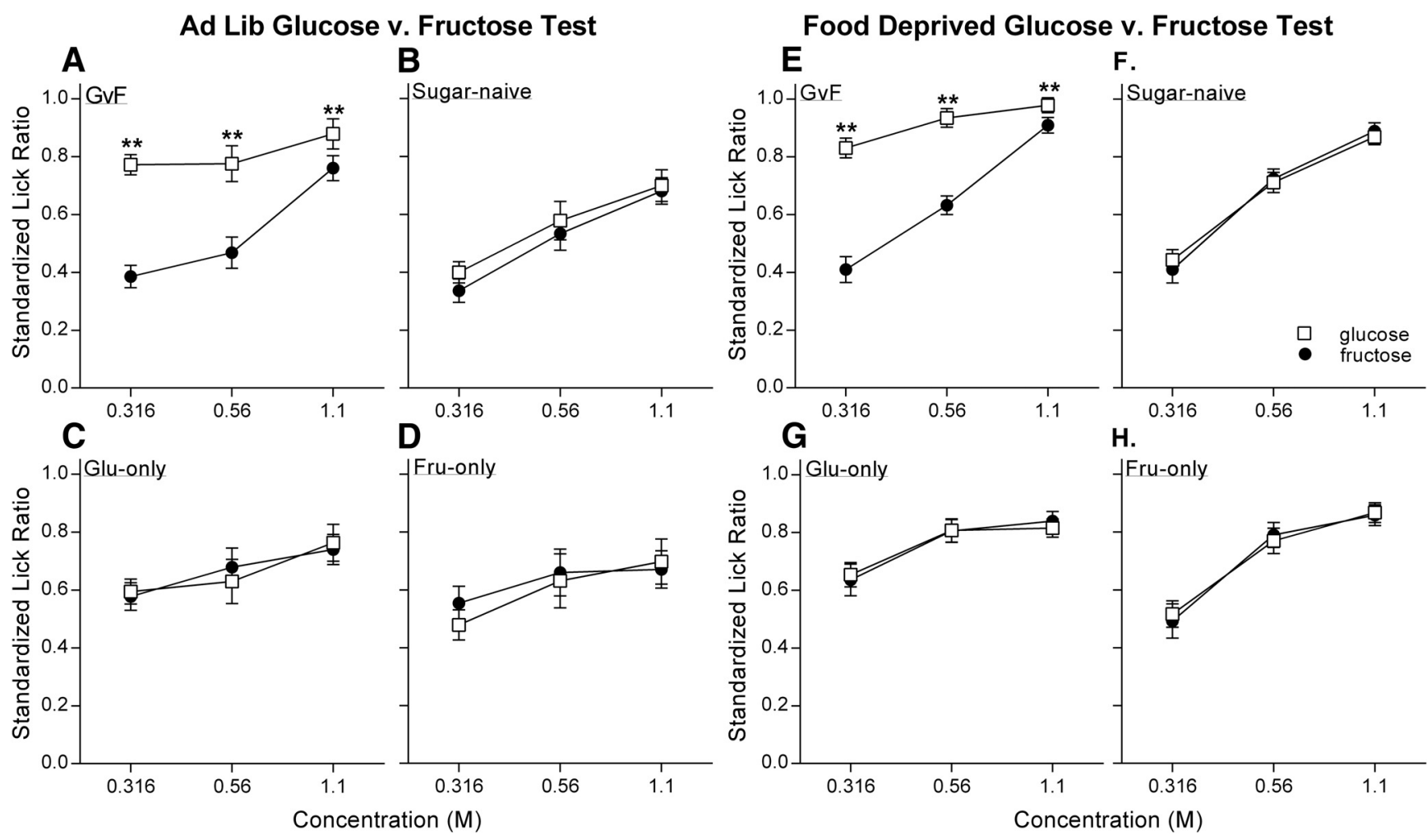

Figure 6. Mean \pm SEM standardized lick ratios to the training concentrations of glucose and fructose presented in randomized order in 15 -s trials on the brief access taste test in the ad libitum versus the food-deprived state for the $\operatorname{GvF}(\boldsymbol{A}, \boldsymbol{E})$, sugar-naive $(\boldsymbol{B}, \boldsymbol{F})$, Glu-only $(\boldsymbol{C}, \boldsymbol{G})$, and Fru-only $(\boldsymbol{D}, \boldsymbol{H})$ training groups. Although the number of trials initiated tended to increase with food deprivation overall, relative to the ad libitum state, there were no differences in the number of trials initiated by each training group in either test state: GvF (ad libitum: $44.61 \pm 5.59$; food deprivation: 67.28 \pm 4.80), sugar-naive (ad libitum: $45.75 \pm 5.93$; food deprivation: $71.17 \pm 5.09$ ), Glu-only (ad libitum: $42.17 \pm 6.84$; food deprivation: 63.33 \pm 5.88 ), and Fru-only (ad libitum: $25.50 \pm 7.50$; food deprivation: $57.50 \pm 6.44$ ) (ad libitum: $F_{(3,24)}=0.05, p=0.98 ;$ food deprivation: $\left.F_{(3,24)}=1.01, p=0.41\right)$. ${ }^{*}$ Significant effect of stimulus in Bonferroni-corrected comparisons at the indicated concentration. The corresponding three-way ANOVA results for each condition (ad libitum and food deprivation tests) are presented in Table 4.

ioral and physiological responses. Perhaps the most compelling evidence for this comes from the post-training brief access taste tests. A critical feature of this test is the random and serial presentation of taste stimuli in brief (here, 15-s) trials; in effect, this precludes the amount of stimulus ingested during a given trial and thus probes licking responses that are explicitly under the control of orosensory input. Under these testing conditions, sugar-naive rats and single sugar-experienced rats licked comparably for each concentration of glucose and fructose, whereas GvF-trained rats selectively licked more for glucose. To our knowledge, this provides the first behavioral demonstration that the affective valence of the orosensory properties of these two sugars can be dissociated, and, as such, indicates that these two sugars must elicit separate orosensory signals.

There have been reasons to doubt the single T1R2 + T1R3 heterodimeric receptor model for sugars over the years (Ackroff and Sclafani, 1991; e.g., Ramirez, 1994; Spector et al., 1997; Eylam and Kennedy, 1998; Damak et al., 2003; Ohkuri et al., 2009), but these have always been met with equally compelling data to suggest that humans and rodents are simply unable to perceive any qualitative differences among the tastes of sugars, with the possible exception of maltose (e.g., Breslin et al., 1996; Spector et al, 1997; Dotson and Spector, 2007). It is, however, important to bear in mind that taste signals are processed for at least three distinct domains of function: stimulus identification, affective/motivation, and digestive preparation (Spector and Glendinning, 2009). Accordingly, Glendinning et al. (2015) demonstrated that the effects of glucose/sucrose and fructose taste are functionally dissociated, not only from each other, but from the T1R3 receptor subunit, with respect to a known physiological output of the gustatory system (i.e., the CPIR). This, coupled with the fact that T1R3 KO mice failed to behaviorally respond to all three sugars in brief access taste tests, was taken to suggest that the gustatory system comprises at least two functionally dissociated pathways for sugars. In this view, all sugars are mediated through the T1R2+T1R3-dependent pathway to higher-order structures (e.g., in ventral forebrain, limbic system) that process the input for quality and affective significance (e.g., palatability, hedonic value), but only a subset of sugars (i.e., glucose and sucrose) additionally engage an alternative peripheral receptor that projects to brainstem structures, where the information is subconsciously processed for metabolic purposes and not further subjected to hedonic or motivational processing.

The results from the present study would appear to support this insofar as sugar-naive and single sugar-trained rats responded to glucose and fructose as though they have identical affective values. However, the pattern of responding in the GvF group strongly suggests that an alternative signal(s) generated by glucose and/or fructose is conveyed to the central sites that process hedonic or motivational valence as well. Thus, we propose that the common signals elicited from the canonical sugar receptor as well as those generated from T1R2+T1R3-independent receptor(s) or otherwise distinct signaling pathways are ultimately both transmitted to gustatory circuits that process information for the purposes of ingestive behaviors. Under some conditions (e.g., naive animal) signals from the T1R2+T1R3 prevail, whereas signals from the other receptor(s) (including possibly T1R2 and/or T1R3 homodimers) and/or signaling pathways 
Table 4. ANOVA values on the post-training brief access test standardized lick ratios

\begin{tabular}{|c|c|c|c|c|c|c|c|}
\hline $\begin{array}{c}\text { Test } \\
\text { Condition } \\
\text { or Test } \\
\text { Stimuli }\end{array}$ & $\begin{array}{l}\text { Group } \\
\text { Effect }\end{array}$ & $\begin{array}{l}\text { Stimulus } \\
\text { Effect }\end{array}$ & $\begin{array}{l}\text { Conc. } \\
\text { Effect }\end{array}$ & $\begin{array}{l}\text { Group x } \\
\text { Stimulus }\end{array}$ & $\begin{array}{l}\text { Group x } \\
\text { Conc. }\end{array}$ & $\begin{array}{l}\text { Stimulus x } \\
\text { Conc. }\end{array}$ & $\begin{array}{l}\text { Group x } \\
\text { Stimulus x } \\
\text { Conc. }\end{array}$ \\
\hline \multicolumn{8}{|c|}{ Glucose versus Fructose Tests } \\
\hline \multirow[t]{5}{*}{ Ad lib } & $\begin{array}{c}F(3,23)=2.61 \\
p=0.08\end{array}$ & $\begin{array}{c}F(1,23)=13.17 \\
p=0.001\end{array}$ & $\begin{array}{c}F(2,46)=43.21 \\
p<0.00001\end{array}$ & $\begin{array}{c}F(3,23)=14.76 \\
p<0.00001\end{array}$ & $\begin{array}{c}F(6,46)=2.24 \\
p=0.06\end{array}$ & $\begin{array}{c}F(2,46)=1.07 \\
p=0.35\end{array}$ & $\begin{array}{c}F(6,46)=3.26 \\
p=0.009\end{array}$ \\
\hline & GvF $(n=9)$ & $\begin{array}{c}F(1,8)=53.45 \\
p=0.00008\end{array}$ & $\begin{array}{c}F(2,16)=24.53 \\
p=0.00001\end{array}$ & & & $\begin{array}{c}F(2,16)=7.28 \\
p=0.006\end{array}$ & \\
\hline & Naïve $(n=8)$ & $\begin{array}{c}F(1,7)=1.91 \\
p=0.21\end{array}$ & $\begin{array}{c}F(2,14)=42.78 \\
p<0.00001\end{array}$ & & & $\begin{array}{c}F(2,14)=0.33 \\
p=0.73\end{array}$ & \\
\hline & $\begin{array}{c}\text { Glu-only } \\
(n=6)\end{array}$ & $\begin{array}{c}F(1,5)=0.006 \\
p=0.94\end{array}$ & $\begin{array}{c}F(2,10)=4.44 \\
p=0.04\end{array}$ & & & $\begin{array}{c}F(2,10)=1.03 \\
p=0.39\end{array}$ & \\
\hline & $\begin{array}{l}\text { Fru-only } \\
(n=4)\end{array}$ & $\begin{array}{c}F(1,3)=0.60 \\
p=0.18\end{array}$ & $\begin{array}{c}F(2,6)=2.70 \\
p=0.15\end{array}$ & & & $\begin{array}{c}F(2,6)=1.65 \\
p=0.27\end{array}$ & \\
\hline \multirow[t]{5}{*}{$\begin{array}{c}\text { Food- } \\
\text { deprived }\end{array}$} & $\begin{array}{c}F(3,24)=4.28 \\
p=0.01\end{array}$ & $\begin{array}{c}F(1,24)=20.59 \\
p=0.0001\end{array}$ & $\begin{array}{c}F(2,48)=159.08 \\
p<0.00001\end{array}$ & $\begin{array}{c}F(3,24)=25.54 \\
p<0.00001\end{array}$ & $\begin{array}{c}F(6,48)=5.34 \\
p=0.0003\end{array}$ & $\begin{array}{c}F(2,48)=12.37 \\
p<0.000001\end{array}$ & $\begin{array}{c}F(6,48)=7.54 \\
p=0.00001\end{array}$ \\
\hline & GvF $(n=9)$ & $\begin{array}{c}F(1,8)=59.92 \\
p=0.00006\end{array}$ & $\begin{array}{c}F(2,16)=65.13 \\
P<0.00001\end{array}$ & & & $\begin{array}{c}F(2,16)=29.50 \\
p<0.00001\end{array}$ & \\
\hline & Naïve $(n=8)$ & $\begin{array}{c}F(1,7)=0.0002 \\
p=0.99\end{array}$ & $\begin{array}{c}F(2,14)=68.27 \\
p<0.00001\end{array}$ & & & $\begin{array}{c}F(2,14)=1.24 \\
p=0.32\end{array}$ & \\
\hline & $\begin{array}{c}\text { Glu-only } \\
(n=6)\end{array}$ & $\begin{array}{c}F(1,5)=0.004 \\
p=0.95\end{array}$ & $\begin{array}{c}F(2,10)=12.22 \\
p=0.002\end{array}$ & & & $\begin{array}{c}F(2,10)=0.63 \\
p=0.55\end{array}$ & \\
\hline & $\begin{array}{l}\text { Fru-only } \\
(n=5)\end{array}$ & $\begin{array}{c}F(1,4)=0.02 \\
p=0.91\end{array}$ & $\begin{array}{c}F(2,8)=42.77 \\
p=0.00005\end{array}$ & & & $\begin{array}{c}F(2,8)=0.30 \\
p=0.75\end{array}$ & \\
\hline \multicolumn{8}{|c|}{ Na-Saccharin, Galactose, and Na -Saccharin versus Galactose Tests } \\
\hline $\begin{array}{c}\mathrm{Na}- \\
\text { Saccharin }\end{array}$ & $\begin{array}{c}F(3,24)=2.54 \\
p=0.08\end{array}$ & & $\begin{array}{c}F(6,144)=60.41 \\
p<0.00001\end{array}$ & & $\begin{array}{c}F(18,144)=1.89 \\
p=0.02\end{array}$ & & \\
\hline Galactose & $\begin{array}{c}F(3,24)=0.83 \\
p=0.49\end{array}$ & & $\begin{array}{c}F(6,144)=223.5 \\
p<0.00001\end{array}$ & & $\begin{array}{c}F(18,144)=0.69 \\
p=0.81\end{array}$ & & \\
\hline $\begin{array}{c}\mathrm{Na}- \\
\text { Saccharin } \\
\text { v. } \\
\text { Galactose }\end{array}$ & $\begin{array}{c}F(3,24)=0.82 \\
p=0.50\end{array}$ & $\begin{array}{c}F(1,24)=13.92 \\
p=0.001\end{array}$ & $\begin{array}{c}F(2,48)=404.83 \\
, p<0.00001\end{array}$ & $\begin{array}{c}F(3,24)=0.49 \\
p=0.69\end{array}$ & $\begin{array}{c}F(6,48)=0.65 \\
p=0.69\end{array}$ & $\begin{array}{c}F(2,48)=46.62 \\
p<0.00001\end{array}$ & $\begin{array}{c}F(6,48)=0.66 \\
p=0.68\end{array}$ \\
\hline
\end{tabular}

Significant effects in italics.

are more or less dismissed. Under different conditions (e.g., explicitly learned dissociations), the alternative signal(s) becomes more hedonically salient and/or motivationally significant.

Although parsimony would favor the involvement of the same T1R2+T1R3-independent receptor that Glendinning et al. (2015) provisionally linked to CPIR in the behavioral effects we found here, future work will need to confirm this or else identify yet a third sugar receptor/pathway. Incidentally, we did not measure CPIR in the present study, but it does not appear that our GvF rats simply learned to use CPIR or any other corollary humoral event to discern glucose from fructose. For one thing, these sorts of humoral responses tend to arise latently, $\sim 3-5 \mathrm{~min}$, after taste stimulation and generally remain elevated for extended periods of time ( $>5 \mathrm{~min}$ ) (e.g., Berthoud et al., 1981; Glendinning et al., 2015). Because the two sugars were serially presented in a randomized order of brief trials at test, any such response elicited to glucose, for example, would also be on board during subsequent trials with fructose, making a discrimination on this basis next to impossible.

Still, the specific patterns of licking for glucose versus fructose solutions in the brief access test by the GvF group make it tempting to speculate that this yet-to-be-identified pathway is related to glucose, not fructose per se. Whereas sugar-naive rats licked in a concentration-dependent manner for both glucose and fructose solutions at test, GvF rats licked practically at ceiling for all three concentrations of glucose but maintained normal concentration-dependent licking for fructose. Indeed, close inspection of the changes in lick rates in the first minute of the training sessions revealed a progressive change that was likewise seemingly specific to glucose. Initially, GvF rats responded to glucose and fructose concentrations in a similar manner (i.e., highest lick rates at the $1.1 \mathrm{M}$ concentrations relative to the two lower concentrations), but, as training progressed, the initial lick rates for the low and middle concentrations of glucose increased, whereas the concentration-dependent responding to fructose remained intact. That said, it is important to note that neither the response profiles from this brief access test nor those from the intermixed single stimulus sessions reflect an isolated or absolute index of hedonic value; rather, responding in both situations is relative to the other stimuli presented. As such, we cannot entirely rule out the possibility that specific features of the fructose signal did not (also) undergo revision with GvF training.

A distinct possibility is that the differential signal arises from the putative "polysaccharide" receptor proposed by Sclafani and 

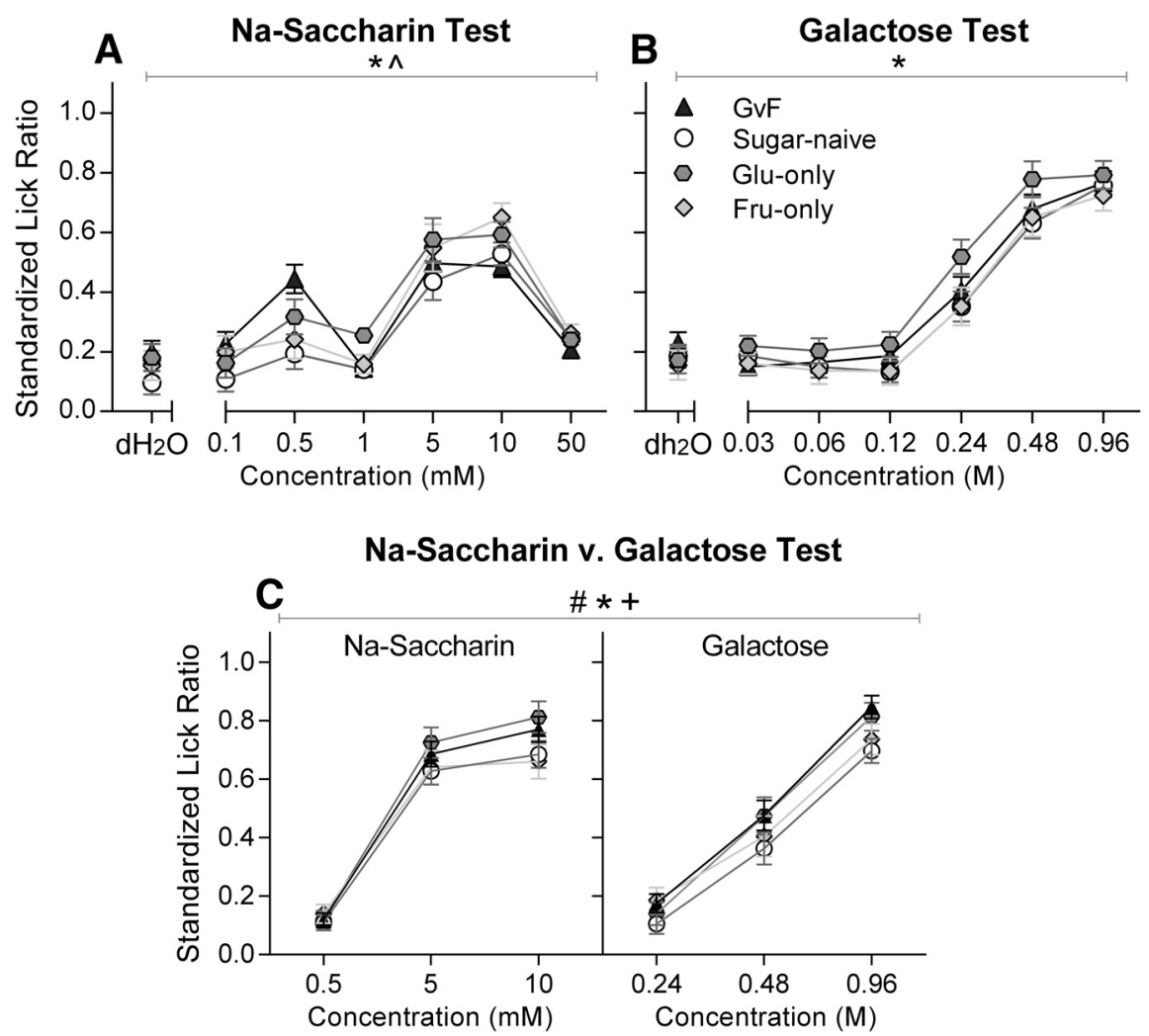

Figure 7. Mean \pm SEM standardized lick ratios for six concentrations $\left(\right.$ and $\left.\mathrm{dH}_{2} 0\right)$ of Na-saccharin $(\boldsymbol{A})$ and galactose $(\boldsymbol{B})$ presented in separate brief access tests. Mean \pm SEM standardized lick ratios for three concentrations of Na-saccharin versus galactose presented in randomized order in the same brief access test ( $\boldsymbol{C}$. Each training group is represented by the same symbol type in each panel. There were no differences in the number of trials initiated across training groups on any of these tests: Na-saccharin (GvF: $59.78 \pm 4.19$; sugar-naive: $58.75 \pm 4.45$; Glu-only: $60.33 \pm 5.13$; Fru-only: $48.60 \pm 5.62 ; F_{(3,24)}=1.06, p=$ 0.38); galactose (GvF: $61.89 \pm 5.45$; sugar-naive: $60.88 \pm 5.78$; Glu-only: $61.50 \pm 6.67$; Fru-only: $58.40 \pm 7.31 ; F_{(3,24)}=0.05$, $p=0.98$ ); Na-saccharin versus galactose (GvF: $54.89 \pm 3.91$; sugar-naive: $57.75 \pm 4.15$; Glu-only: $50.83 \pm 4.79$; Fru-only: $\left.57.60 \pm 5.25 ; F_{(3,24)}=0.47, p=0.70\right)$. "Significant main effect of stimulus. *Significant main effect of concentration. ^ Significant group $\times$ concentration. ${ }^{+}$Significant stimulus $\times$concentration. The full statistical outcomes for each test are presented in Table 4.

colleagues nearly 30 years ago (Nissenbaum and Sclafani, 1987). Although the exact identity of this receptor(s) is still unknown, there is ample evidence to suggest that not only are the longer-chain glucose polymers and starches principally mediated by a T1R2 + T1R3-independent receptor, but they elicit a qualitatively distinct taste from the simple sugars (e.g., Sclafani et al., 1987; Nissenbaum and Sclafani, 1987; Zukerman et al., 2009; Treesukosol et al., 2011). Recent data from naive T1R single subunit $\mathrm{KO}$ and T1R2 + T1R3 double KO mice suggest that T1R2 and/or T1R3 are necessary for normal behavioral responsivity to glucose, maltose, and maltotriose in the brief access test, but are not necessary for taste-guided responsivity to solutions containing longer glucose chains (i.e., Polycose) (Treesukosol et al., 2011). Interestingly, however, one study showed that taste aversions conditioned to Polycose subsequently generalized to glucose, but not fructose (Nissenbaum and Sclafani, 1987), suggesting that glucose may share some orosensory properties with this polysaccharide. Moreover, rats appear to discriminate the taste of sucrose from maltose (two glucose moieties) in a way that cannot be readily explained by intensity (Spector and Grill, 1988; Spector et al., 1997). Thus, perhaps even if glucose (and 1-3 chain glucose moieties) is a relatively weak stimulus for the alternative carbohydrate ("polysaccharide") receptor, the generated signal can become sufficiently salient under some conditions.
Experience consuming glucose or fructose in these single sugar training groups (i.e., Glu-only or Fru-only) fostered greater responsivity to the training sugar (especially at the low and mid concentrations) in the first minute of each successive training session. However, these same two groups did not display preferential responding for one sugar over the other in the brief access tests; if anything, both groups appeared to have an especially elevated response to the low concentrations of both sugars, relative to the sugar-naive group. It would appear then the lack of an opportunity to differentially compare the two sugars during training led the Glu-only and Fru-only groups to generalize their sensory experience to the other sugar. This could be an example of a context in which the signals arising from the T1R2+T1R3 heterodimer prevail to guide behavior.

The present results also add to the growing evidence that some postoral stimuli positively affect ongoing ingestion. These sorts of within-meal appetition effects have been largely overlooked in the past because they are ultimately obscured by the later satiating effects of the food or fluid, even in relatively short-term (e.g., $30 \mathrm{~min}$ ) intake measures (Sclafani and Ackroff, 2012a). Indeed, with more temporally resolute measures, the appetition effect manifests as a transient increase in the rate of ingestion, shortly after the start of a meal with or intragastric/intraintestinal infusion of certain nutrients (e.g., Zukerman et al., 2011, 2013; Myers et al., 2013; Ackroff and Sclafani, 2014). With respect to glucose and fructose, studies have shown that postoral fructose is not as appetitious as glucose, nor is it as effective at reinforcing long-term flavor preferences (Sclafani and Ackroff, 1994, 2012b, 2015; e.g., Glendinning et al., 2010). However, there has always been uncertainty as to whether fructose exerts more negative consequences than glucose, which, in turn, counteract its positive effects (or vice versa). Here, we show that rats initially licked at comparable rates to $0.56 \mathrm{M}$ glucose and fructose on Session 1, suggesting that the earliest unconditioned orosensory-driven responses are matched. Whereas glucose then appears to elicit immediate positive feedback that functions to keep the central pattern generator on and the rat engaged in actively consuming that stimulus, with fructose this positive effect appears to be weaker and somewhat delayed. Whatever the case, the "less positive" net effect of fructose cannot be simply due to greater negative postoral feedback signals because these rats continue to engage in appetitive behaviors, as indicated by the increased number of initiated bursts, as the session progresses.

Although it is clear that the precise molecular and neural mechanisms that mediate the differential responses to orosensory properties of glucose and fructose now require more systematic investigation that will benefit from a complement of other experimental approaches, the present study especially underscores the fact that understanding the full behavioral purview of 
the animal, including experience, provides important insights for how the gustatory system is organized.

\section{References}

Ackroff K, Sclafani A (1991) Flavor preferences conditioned by sugars: rats learn to prefer glucose over fructose. Physiol Behav 50:815-824. CrossRef Medline

Ackroff K, Sclafani A (2014) Post-oral fat stimulation of intake and conditioned flavor preference in C57BL/6J mice: a concentration-response study. Physiol Behav 129:64-72. CrossRef Medline

Berthoud HR, Bereiter DA, Trimble ER, Siegel EG, Jeamrenaud B (1981) Cephalic phase insulin secretion: neuroanatomical and physiological characterization. Diabetologia 20 [Suppl]:393-401.

Breslin PA, Beauchamp GK, Pugh EN Jr (1996) Monogeusia for fructose, glucose, sucrose, and maltose. Percept Psychophys 58:327-341. CrossRef Medline

Damak S, Rong M, Yasumatsu K, Kokrashvili Z, Varadarajan V, Zou S, Jiang P, Ninomiya Y, Margolskee RF (2003) Detection of sweet and umami taste in the absence of taste receptor T1R3. Science 301:850-853. CrossRef Medline

Davis JD (1973) The effectiveness of some sugars in stimulating licking behavior in the rat. Physiol Behav 11:39-45. CrossRef Medline

Davis JD (1999) Some new developments in the understanding of oropharyngeal and postingestional controls of meal size. Nutrition 15:32-39. CrossRef Medline

Davis JD, Perez MC (1993) Food deprivation- and palatability-induced micro-structural changes in ingestive behavior. Am J Physiol Regul Integr Comp Physiol 264:R97-R103. Medline

Davis JD, Smith GP (1992) Analysis of the microstructure of the rhythmic tongue movements of rats ingesting maltose and sucrose solutions. Behav Neurosci 106:217-228. CrossRef Medline

Dotson CD, Spector AC (2007) Behavioral discrimination between sucrose and other natural sweeteners in mice: implications for the neural coding of T1R ligands. J Neurosci 27:11242-11253. CrossRef Medline

Dyer J, Vayro S, King TP, Shirazi-Beechey SP (2003) Glucose sensing in the intestinal epithelium. Eur J Biochem 270:3377-3388. CrossRef Medline

Eylam S, Kennedy LM (1998) Identification and characterization of human fructose or glucose taste variants with hypogeusia for one monosaccharide but not for the other. Ann N Y Acad Sci 855:170-174. CrossRef Medline

Glendinning JI, Beltran F, Benton L, Cheng S, Gieseke J, Gillman J, Spain HN (2010) Taste does not determine daily intake of sugar solutions in mice. Am J Physiol Regul Integr Comp Physiol 299:R1333-R1341. CrossRef Medline

Glendinning JI, Stano S, Holter M, Azenkot T, Goldman O, Margolskee RF, Vasselli JR, Sclafani A (2015) Sugar-induced cephalic-phase insulin release is mediated by a T1r2+T1r3-independent taste transduction pathway in mice. Am J Physiol Regul Integr Comp Physiol 309:R552-R560. CrossRef Medline

Li X, Staszewski L, Xu H, Durick K, Zoller M, Adler E (2002) Human receptors for sweet and umami. Proc Natl Acad Sci U S A 99:4692-4696. CrossRef Medline

Merigo F, Benati D, Cristofoletti M, Osculati F, Sbarbati A (2011) Glucose transporters are expressed in taste receptor cells. J Anat 219:243-252. CrossRef Medline

Myers KP, Taddeo MS, Richards EK (2013) Sensory-specific appetition: postingestive detection of glucose rapidly promotes continued consumption of a recently encountered flavor. Physiol Behav 121:125-133. CrossRef Medline

Nelson G, Hoon MA, Chandrashekar J, Zhang Y, Ryba NJ, Zuker CS (2001) Mammalian sweet taste receptors. Cell 106:381-390. CrossRef Medline

Nissenbaum JW, Sclafani A (1987) Qualitative differences in polysaccharide and sugar tastes in the rat: a two-carbohydrate taste model. Neurosci Biobehav Rev 11:187-196. CrossRef Medline

Ohkuri T, Yasumatsu K, Horio N, Jyotaki M, Margolskee RF, Ninomiya Y (2009) Multiple sweet receptors and transduction pathways revealed in knockout mice by temperature dependence and gurmarin sensitivity. Am J Physiol Regul Integr Comp Physiol 296:R960-R971. CrossRef Medline

O’Malley D, Reimann F, Simpson AK, Gribble FM (2006) Sodium coupled glucose cotransporters contribute to hypothalamic glucose-sensing. Diabetes 55:3381-3386. CrossRef Medline

Ramirez I (1994) Sucrose and fructose have qualitative different flavors to rats. Physiol Behav 56:549-554. CrossRef Medline

Sclafani A, Ackroff K (1994) Glucose- and fructose-conditioned flavor preferences in rats: taste versus postingestive conditioning. Physiol Behav 56:399-405. CrossRef Medline

Sclafani A, Ackroff K (2012a) Role of gut nutrient sensing in stimulating appetite and conditioning food preferences. Am J Physiol Regul Integr Comp Physiol 302:R1119-R1133. CrossRef Medline

Sclafani A, Ackroff K (2012b) Flavor preferences conditioned by intragastric glucose but not fructose or galactose in C57BL/6J mice. Physiol Behav 106:457-461. CrossRef Medline

Sclafani A, Ackroff K (2015) Flavor preference conditioning by different sugars in sweet ageusic Trpm5 knockout mice. Physiol Behav 140:156163. CrossRef Medline

Sclafani A, Hertwig H, Vigorito M, Sloan H, Kerzner B (1987) Influence of saccharide length on polysaccharide appetite in the rat. Neurosci Biobehav Rev 11:197-200. CrossRef Medline

Spector AC (2003) Psychophysical evaluation of taste function in nonhuman mammals. In: Handbook of olfaction and gestation (Doty RL, ed), Ed 2, pp 861-879. New York: Marcel Dekker.

Spector AC, Glendinning JI (2009) Linking peripheral taste processes to behavior. Curr Opin Neurobiol 19:370-377. CrossRef Medline

Spector AC, Grill HJ (1988) Differences in the taste quality of maltose and sucrose in rats: issues involving the generalization of conditioned taste aversions. Chem Senses 13:95-113. CrossRef

Spector AC, St. John SJ (1998) Role of taste in the microstructure of quinine ingestion by rats. Am J Physiol Regul Integr Comp Physiol 274: R1687-R1703. Medline

Spector AC, Markison S, St. John SJ, Garcea M (1997) Sucrose vs. maltose taste discrimination by rats depends on the input of the seventh cranial nerve. Am J Physiol Regul Integr Comp Physiol 272:R1210-R1218. Medline

Spector AC, Klumpp PA, Kaplan JM (1998) Analytical issues in the evaluation of food deprivation and sucrose concentration effects on the microstructure of licking behavior in the rat. Behav Neurosci 112:678-694. CrossRef Medline

Spector AC, Blonde GD, Henderson RP, Treesukosol Y, Hendrick P, Newsome R, Fletcher FH, Tang T, Donaldson JA. (2015) A new gustometer for taste testing in rodents. Chem Senses 40:187-196. CrossRef Medline

Toyono T, Seta Y, Kataoka S, Oda M, Toyoshima K (2011) Differential expression of the glucose transporters in mouse gustatory papillae. Cell Tiss Res 345:243-252. CrossRef Medline

Treesukosol Y, Spector AC (2012) Orosensory detection of sucrose, maltose, and glucose is severely impaired in mice lacking T1R2 or T1R3, but Polycose sensitivity remains relatively normal. Am J Physiol Regul Integr Comp Physiol 303:R218-R235. CrossRef Medline

Treesukosol Y, Smith KR, Spector AC (2011) Behavioral evidence for a glucose polymer taste receptor that is independent of the T1R2+3 heterodimer in a mouse model. J Neurosci 31:13527-13534. CrossRef Medline

Wright EM, Sala-Rabanal M, Loo DDF, Hirayama BA (2012) Sugar absorption. In: Physiology of the gastrointestinal tract (Johnson L, ed), pp 1583-1593. Boston: Academic

Yee KK, Sukumaran SK, Kothaa R, Gilbertson TA, Margolskee RF (2011) Glucose transporters and ATP-gated K+ (KATP) metabolic sensors are present in type 1 taste receptor 3 (T1r3)-expressing taste cells. Proc Natl Acad Sci U S A 108:5431-5436. CrossRef Medline

Zhao GQ, Zhang Y, Hoon MA, Chandrashekar J, Erlenbach I, Ryba NJ, Zuker CS (2003) The receptors for mammalian sweet and umami taste. Cell 115:255-266. CrossRef Medline

Zukerman S, Glendinning JI, Margolskee RF, Sclafani A (2009) T1R3 taste receptor is critical for sucrose but not Polycose taste. Am J Physiol Regul Integr Comp Physiol 296:R866-R876. CrossRef Medline

Zukerman S, Ackroff K, Sclafani A (2011) Rapid postoral stimulation of intake and flavor conditioning by glucose and fat in the mouse. Am J Physiol Regul Integr Comp Physiol 301:R1635-R1647. CrossRef Medline

Zukerman S, Ackroff K, Sclafani A (2013) Post-oral appetite stimulation by sugars and nonmetabolizable sugar analogs. Am J Physiol Regul Integr Comp Physiol 305:R840-R853. CrossRef Medline 